\title{
Identification of Polyphenols and Anti-Oxidant Capacity of Piper aduncum $\mathbf{L}$.
}

\author{
Mónica Ramos Escudero ${ }^{\mathrm{a}}$, D. Fernando Ramos Escudero ${ }^{\mathrm{b}}$, Connie M. Remsberg ${ }^{\mathrm{c}}$, Jody K. \\ Takemoto $^{c}$, Neal M. Davies ${ }^{c}, J^{2}$ ime A. Yáñez,cc
}

\begin{abstract}
${ }^{a}$ Escuela de Postgrado en Agricultura Sostenible, Universidad Nacional Agraria de la Selva, Tingo María, Perú, ${ }^{b}$ Centro de Investigación de Bioquímica y Nutrición, Facultad de Medicina Humana, Universidad de San Martín de Porres, Lima, Perú, 'College of Pharmacy Department of Pharmaceutical Sciences and Pharmacology and Toxicology Graduate Program, Washington State University, Pullman, WA 99164-6534, USA
\end{abstract}

\begin{abstract}
Ethanol extracts of Piper aduncum L. leaves from five sub-regions in the tropical Peruvian rainforest were assessed for polyphenol content utilizing liquid chromatography coupled with mass spectrometry with electrospray ionization (LC-MS-ESI). The anti-oxidant capacity was estimated using a DPPH radical scavenging assay. Additionally, the reducing power (capacity to reduce $\mathrm{Fe}^{3+}$ to $\mathrm{Fe}^{2+}$ ), the capacity to scavenge hydrogen peroxide and the total polyphenol content, were assessed. Analysis led to the identification of gallic acid, catechin, chlorogenic acid, epicatechin, rutin, quercitrin, phloridzin, quercetin, and phloretin, as well as determination of potent anti-oxidant capacities by P. aduncum L.
\end{abstract}

Key Words: Piper aduncum L., matico, polyphenol, DPPH, anti-oxidant, Peru.

\section{INTRODUCTION}

The identification and characterization of anti-oxidant compounds from plant sources has become an active research area because compounds such as polyphenols act as primary anti-oxidants and free radical scavengers. Polyphenols exhibit multiple pharmacological properties such as anti-microbial, anti-allergenic, anti-ulcerogenic, anti-neoplastic, and anti-inflammatory activities [1]. The polyphenol family includes phenolic acids, stilbenes, chalcones, coumarins, cromones, lignans, flavonoids, isoflavonoids, neoflavonoids, and tannins. The polyphenol family has been shown to possess significant anti-oxidant capacities, while maintaining low toxicities [2].

The Piper aduncum L. species (Piperaceae), locally known as "Matico", has long been used in alternative medicine as an antiseptic for wound healing, and as treatment for haemostasis, dysentery, chronic diarrhea, common cold and gastrointestinal pain in multiple countries [3]. Its essential oils have also shown biological activity including strong anti-bacterial, cytotoxic, fungistatic, insecticidal, and molluscidal activities [4]. From a chemical standpoint, a variety of phenolic secondary metabolites such as lignans, chalcones, dihydrochalcones, chromene, and benzoic acid derivatives have been isolated from $P$. aduncum L. [5]. Other well known plants in the Piper genus include black pepper (Piper nigrum) and kava-kava (Piper methysticum).

$P$. aduncum L. is one of the 429 species that belong to the Piperaceae family that have been identified in Peru alone [6]. It is widespread in north and central eastern Peru and it

*Address correspondence to this author at the Schering-Plough Research Institute, Drug Metabolism and Pharmacokinetics, 2015 Galloping Hill Road, Mail Stop K15-3 3700, Kenilworth, NJ 07033, USA; Tel: (908) 4878777; E-mail: jaimeayanez@gmail.com remains as one of the most widely employed phytotherapy agents by local communities. The local herbal market also widely employs it in multiple compositions. Although used widely, no anti-oxidant assessment has been performed and little ethnobotanical or phytochemical research on this species has been conducted. In the present work, liquid chromatography coupled with mass spectrometry and electrospray ionization (LC-MS-ESI) was employed to identify individual polyphenols of ethanol extracts from leaves of $P$. aduncum L. collected from five sub-regions of the tropical Peruvian rainforest. The DPPH radical and hydrogen peroxide scavenging activity, reducing power, and total polyphenol content, were also assessed.

\section{MATERIALS AND METHODS}

\section{Plant Material}

Piper aduncum L. leaves were collected during July 2004 by Mónica Ramos Escudero from five sub-regions (Marona Baja, Tingo Maria, Tulumayo, San Isidro, and Honolulo) of the Huallaga river valley in the Peruvian tropical rainforest. Voucher specimens (Table 1) were deposited at the Museo de Ciencia Natural (Natural Science Museum) of the Universidad Nacional Mayor de San Marcos (UNMSM) in Lima, Peru. The specimens were identified by Hamiltón Beltrán, C. Biol. based on the leaf characteristics [7].

\section{Extraction and Isolation}

The powdered air-dried leaves $(1 \mathrm{~kg})$ were extracted with $95 \%$ ethanol at room temperature under constant shaking for 2 hours. The extract was centrifuged, the supernatant collected and the insoluble material discarded. The extract (supernatant) was dried to completion and the plant material obtained (percentage yield) was between $14.3 \%$ and $16.9 \%$ from the initial dry weight. The total ethanol extracts were diluted to different concentrations (as specified under each 
Table 1. Polyphenol Content $(\mu \mathrm{g} / \mathrm{g}$ Dry Matter) in $P$. aduncum $L$ Ethanol Extracts (mean \pm SEM, $n=4)$ from Different Geographical Sub-Regions

\begin{tabular}{|c|c|c|c|c|c|}
\hline Compound & San Isidro & Honolulo & Tingo María & Tulumayo & Marona Baja \\
\hline Catechin & $0.94 \pm 0.02^{\mathrm{a}}$ & $0.96 \pm 0.03^{\mathrm{a}}$ & $0.95 \pm 0.04^{\mathrm{a}}$ & $0.94 \pm 0.03^{\mathrm{a}}$ & $0.92 \pm 0.02^{\mathrm{a}}$ \\
\hline Epicatechin & $1.34 \pm 0.02^{\mathrm{a}}$ & $1.33 \pm 0.04^{\mathrm{a}}$ & $1.33 \pm 0.01^{\mathrm{a}}$ & $1.28 \pm 0.02^{\mathrm{a}}$ & $1.29 \pm 0.03^{\mathrm{a}}$ \\
\hline Quercetin-3-rutinoside (rutin) & $1.29 \pm 0.03^{\mathrm{a}}$ & $1.22 \pm 0.01^{\mathrm{b}}$ & $1.09 \pm 0.04^{\mathrm{c}}$ & $0.81 \pm 0.05^{\mathrm{d}}$ & $0.64 \pm 0.01^{\mathrm{e}}$ \\
\hline Quercetin-3-rhamnoside (quercitrin) & $1.16 \pm 0.03^{\mathrm{a}}$ & $1.16 \pm 0.04^{\mathrm{a}}$ & $1.14 \pm 0.03^{\mathrm{a}}$ & $1.10 \pm 0.02^{\mathrm{a}}$ & $1.08 \pm 0.02^{\mathrm{a}}$ \\
\hline Phloridzin & $6.00 \pm 0.03^{\mathrm{a}}$ & $5.58 \pm 0.02^{\mathrm{a}}$ & $5.50 \pm 0.02^{\mathrm{a}}$ & $4.29 \pm 0.02^{\mathrm{a}}$ & $3.99 \pm 0.02^{\mathrm{a}}$ \\
\hline TOTAL & $29.06 \pm 0.22^{\mathrm{a}}$ & $27.17 \pm 0.19^{b}$ & $26.19 \pm 0.24^{\mathrm{c}}$ & $20.57 \pm 0.29^{d}$ & $17.86 \pm 0.18$ \\
\hline
\end{tabular}

${ }^{1}$ Different letters in the same row indicate statistical differences $(\mathrm{p}<0.05)$.

experimental section) and were tested for radical activity by DPPH assay, hydrogen peroxide scavenging activity, and reducing power. For LC-MS-ESI analysis, the ethanol extracts were dried under a constant flow of compressed nitrogen gas, and reconstituted in mobile phase before injection.

\section{LC-MS-ESI Analysis}

The chromatographic conditions previously described [8] were slightly modified. The modifications included using a Phenomenex Luna (2) $\mathrm{C}_{18}$ column $(250 \times 4.60 \mathrm{~mm}$, i.d. $5 \mu \mathrm{m}$ particle size, Torrance CA, USA), and a guard Phenomenex Luna (2) $\mathrm{C}_{18}$ column $(30 \times 4.60 \mathrm{~mm}$, i.d. $3 \mu \mathrm{m}$ particle size, Torrance CA, USA). Additionally, the mobile phase was altered to consist of $2 \%(\mathrm{v} / \mathrm{v})$ acetic acid in water (eluent $\mathrm{A}$ ) and of $0.5 \%$ acetic acid in water and acetonitrile $(50: 50, \mathrm{v} / \mathrm{v}$; eluent B). The gradient was as follows: $10 \% \mathrm{~B}$ to $55 \% \mathrm{~B}(70$ $\mathrm{min}), 55 \% \mathrm{~B}$ to $100 \% \mathrm{~B}(10 \mathrm{~min}), 100 \% \mathrm{~B}$ to $10 \% \mathrm{~B}(10$ $\mathrm{min})$. The flow rate was as follows: $0.8 \mathrm{~mL} / \mathrm{min}(55 \mathrm{~min}), 1$ $\mathrm{mL} / \mathrm{min}$ (45 $\mathrm{min})$. In order to verify the presence of each compound standard curves $(100 \mathrm{ng} / \mathrm{mL}$ to $50 \mu \mathrm{g} / \mathrm{mL})$ for each compound were prepared for calibration. Each eluted peak was confirmed by its corresponding $\mathrm{m} / \mathrm{z}$ ratio using a Shimadzu LCMS-2010 EV liquid chromatograph mass spectrometer system (Kyoto, Japan) connected to the LC portion consisting of two LC-10AD pumps, a SIL-10AD VP auto injector, a SPD-10A VP UV detector, and a SCL-10A VP system controller. The mass spectrometer conditions consisted of a curved desolvation line (CDL) temperature of $200^{\circ} \mathrm{C}$ and a block temperature of $200^{\circ} \mathrm{C}$. The CDL, interface, and detector voltages were $-20.0 \mathrm{~V}, 4.5 \mathrm{kV}$, and $1.2 \mathrm{kV}$, respectively. Vacuum was maintained by an Edwards ${ }^{\circledR}$ E2M30 rotary vacuum pump (Edwards, UK). Liquid nitrogen (Washington State University Central Stores) was used as a source of nebulizer gas $(1.5 \mathrm{~L} / \mathrm{min})$. In the negativespecific ion mode (SIM) the single plot transitions $(\mathrm{m} / \mathrm{z})$ of each compound were monitored. The injection volume for all samples was $30 \mu \mathrm{L}$, and the internal standard employed was daidzein. Good linearity $\left(\mathrm{R}^{2}>0.998\right)$ for each compound was observed (based on individual standard curves). Recovery for each compound was $>95 \%$.

\section{DPPH Radical Scavenging Assay}

The 1,1-diphenyl-2-picryl-hydrazyl (DPPH) method [9] was modified. Briefly, a $100 \mu \mathrm{M}$ DPPH solution was freshly prepared in methanol. Various concentrations $(0-300 \mu \mathrm{g} / \mathrm{mL})$ of ethanol extracts $(50 \mu \mathrm{L})$ were reacted with $950 \mu \mathrm{L}$ of the DPPH radical solution for 10 minutes at room temperature. Absorbance was measured at $515 \mathrm{~nm}$ and results were compared to the standard, $\alpha$-tocopherol.

\section{Hydrogen Peroxide Scavenging Assay}

The $\mathrm{H}_{2} \mathrm{O}_{2}$ scavenging assay previously described [10] was modified. Briefly, a solution of hydrogen peroxide (50 $\mathrm{mM}$ ) was freshly prepared in phosphate buffered saline (PBS; pH 7.4). Ethanol extracts of P. aduncum L. $(400 \mu \mathrm{L}$ at concentration $100 \mu \mathrm{g} / \mathrm{mL}$ ) were reacted with $600 \mu \mathrm{L}$ of the hydrogen peroxide solution for 30 minutes at room temperature, and absorbance was measured at $230 \mathrm{~nm}$. Ascorbic acid was used as the standard.

\section{Reducing Power}

The reducing power assay allows for the quantification of the capacity of a compound or extract to reduce iron from its ferric state $\left(\mathrm{Fe}^{3+}\right)$ to its ferrous $\left(\mathrm{Fe}^{2+}\right)$ state. The reducing power assay previously described [11] was modified. Briefly, solutions of phosphate buffer $(0.2 \mathrm{M}, \mathrm{pH} 6.6)$, potassium ferricyanide (1\%), stock trichloroacetic acid (TCA) and ferric chloride $\left(\mathrm{FeCl}_{3}, 0.1 \%\right)$ were prepared. Ethanol extracts of $P$. aduncum L. ( $100 \mu \mathrm{L}$ at concentration $100 \mu \mathrm{g} / \mathrm{mL})$ reacted with $2.5 \mathrm{~mL}$ of the phosphate buffer solution and 2.5 
$\mathrm{mL}$ of the potassium ferricyanide solution for 20 minutes at $50^{\circ} \mathrm{C}$. Then, the mixture was combined with $2.5 \mathrm{~mL}$ of TCA, centrifuged at $3000 \mathrm{rpm}$ for 10 minutes at room temperature, and a $2.5 \mathrm{~mL}$ aliquot of the upper layer was obtained. The aliquot was combined with $2.5 \mathrm{~mL}$ of distilled water and 0.5 $\mathrm{mL}$ of $\mathrm{FeCl}_{3}$ solution, and absorbance was measured at 700 nm. Ascorbic acid was used as the standard and in preparation of calibration curves.

\section{Total Polyphenols Content}

The total polyphenol content was measured by the Prussian Blue Assay [12], substituting ferric ammonium sulfate for ferric chloride as previously indicated [13]. Briefly, solutions of ferric chloride $\left(\mathrm{FeCl}_{3}, 0.1 \mathrm{M}\right)$ in $0.1 \mathrm{~N} \mathrm{HCl}$, and another solution of potassium ferricyanide $(0.008 \mathrm{M})$ in water were prepared. Ethanol extracts of $P$. aduncum L. $(1 \mathrm{~mL}$ at concentration $100 \mu \mathrm{g} / \mathrm{mL}$ ) reacted with $3 \mathrm{~mL}$ of the $\mathrm{FeCl}_{3}$ solution and $3 \mathrm{~mL}$ of the potassium ferricyanide solution for 10 minutes at room temperature, and absorbance was measured at $720 \mathrm{~nm}$. Gallic acid was used to prepare the calibration curves.

\section{Statistical Analysis}

Compiled data were presented as mean and standard error of the mean (mean \pm SEM). General Linear Model (GLM) Analysis of Variance (ANOVA) with NewmanKeuls multiple comparison test with a p-value $<0.05$ been statistically significant (NCSS Statistical and Power Analysis, Kaysville, UT).

\section{RESULTS AND DISCUSSION}

The validated LC-MS-ESI method had a limit of quantification (LOQ) of $50 \mathrm{ng} / \mathrm{mL}$ for all the compounds and a coefficient of variation ( $\mathrm{CV} \%$ ) for the different compounds ranging from $3-7 \%$ inter-day and $5-8 \%$ intra-day. Standard curves ranged from $100 \mathrm{ng} / \mathrm{mL}$ to $50 \mu \mathrm{g} / \mathrm{mL}$. As shown in Fig. (1), baseline separation and resolution was achieved for all the compounds and the total ion chromatograms were recorded in the negative ion mode. It was found that the predominant phenolic constituents in Piper aduncum L. were

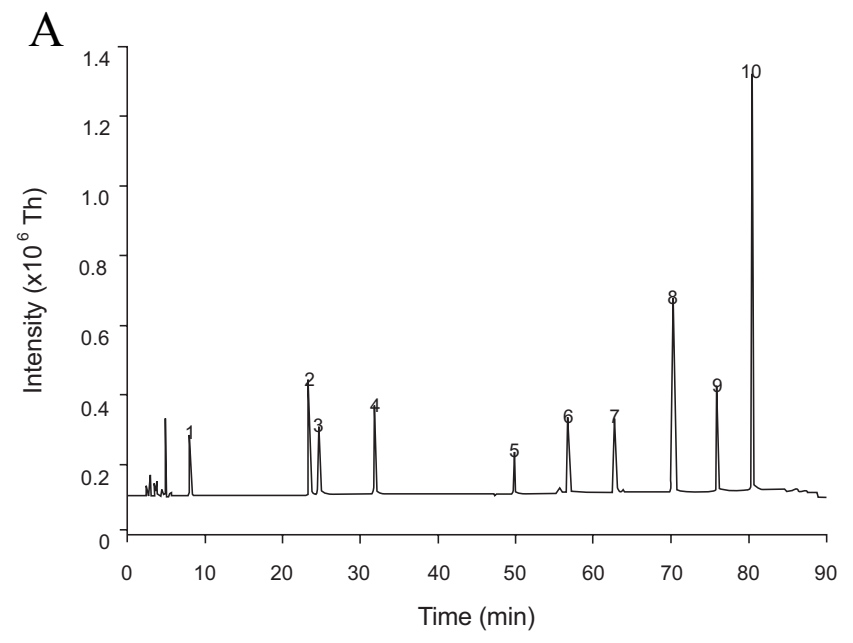

quercetin, phloridzin, and epicatechin followed by quercetin glycosides (quercitrin and rutin), catechin, benzoic acids (gallic acid and chlorogenic acid), and phloretin.

It was observed that the composition in individual phenolics varied depending on the geographical area. However, the content of catechin, epicatechin, and quercetin-3rhamnoside (quercitrin) remained constant independent of the geographical area (Table 1). The total sum of individual phenolics from highest to lowest was San Isidro $>$ Honolulo $>$ Tingo María > Tulumayo > Marona Baja, which correlated with the DDPH radical scavenging, $\mathrm{H}_{2} \mathrm{O}_{2}$ scavenging activity, reducing power, and total polyphenol content (Table 2). The sub-regions from where $P$. aduncum L. was sampled are within a 10 mile-ratio, but based on the statistically significant differences in the measured parameters, geographical location plays an important role. This observation correlates with previous reports that demonstrated that the absence or presence of pharmacologically active substances can vary within the same specimen depending on the collection place, weather conditions, soil characteristics, time of the year when the collection is performed, and farming conditions [14].

The $P$. aduncum L. ethanol extracts exhibited DPPH $\mathrm{IC}_{50}$ values of $85-220 \mu \mathrm{g} / \mathrm{mL}$, which correlate to the values for green tea $(100-300 \mu \mathrm{g} / \mathrm{mL})$ and are slightly lower than the values for black tea $(200-800 \mu \mathrm{g} / \mathrm{mL})$ [15]. Ability to act as a scavenger may be responsible to some extent for the reported biological activities of $P$. aduncum L. The different polyphenols detected (most of them for the first time) in P. aduncum L. may be responsible to some extent for its anti-oxidant capacity since gallic acid, chlorogenic acid, catechin, and quercetin have reported $\mathrm{IC}_{50}$ values of $1-8 \mu \mathrm{g} / \mathrm{mL}$ [16]. However, since $P$. aduncum L. exhibited greater $\mathrm{IC}_{50}$ values than any polyphenolic compound alone, there might be some combinational effects or other factors (e.g. extraction solvent or procedure) yet to be determined. Furthermore, it was observed that $P$. aduncum $\mathrm{L}$. from all the tested sub-regions contains higher hydrogen peroxide scavenging capacity than

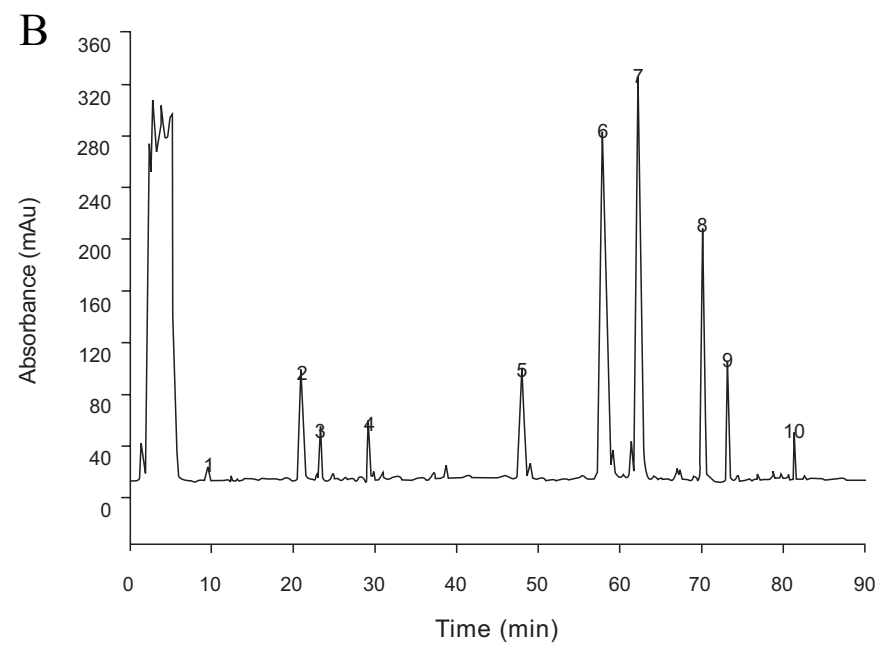

Fig. (1). Chromatograms of ethanol extract of $P$. aduncum L. A) Total ion chromatogram. B) HPLC/UV chromatogram (280 nm). Peak assignment: 1, gallic acid; 2, catechin; 3, chlorogenic acid; 4, epicatechin; 5, quercetin-3-rutinoside (rutin); 6, quercetin-3-rhamnoside (quercitrin); 7, phloridzin; 8, daidzein (internal standard); 9, quercetin; and 10, phloretin. 
Table 2. DPPH Radical Scavenging Activities, Hydrogen Peroxide $\left(\mathrm{H}_{2} \mathrm{O}_{2}\right)$ Scavenging Activities, Reducing Powers, and Total Polyphenol Content of $P$. aduncum L. Ethanol Extracts (mean \pm SEM, $n=4$ ) from Different Geographical Sub-Regions. All, Except the DDPH Radical Scavenging Assay (Concentration Range 0-300 ug/mL), were Performed at Extract Concentration of $100 \mu \mathrm{g} / \mathrm{mL}$ Including the Controls. AAE $=$ Ascorbic Acid Equivalent, GAE = Gallic Acid Equivalent, NA = Not Applicable

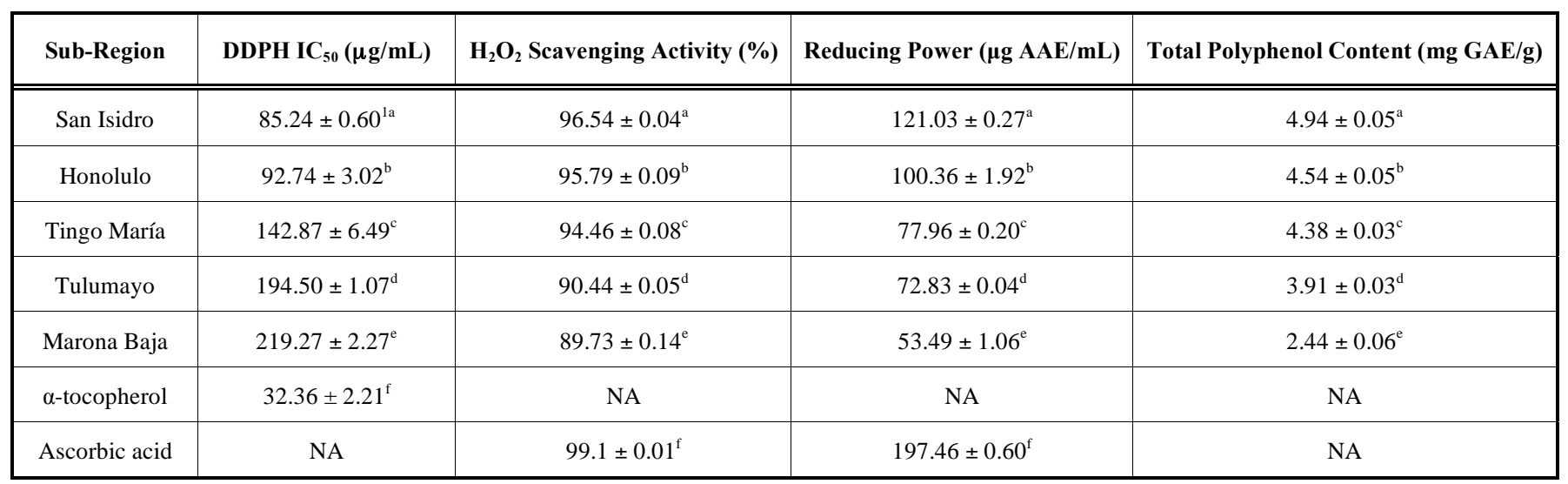

${ }^{1}$ Different letters in the same column indicate statistical differences $(\mathrm{p}<0.05)$.

cat's claw (Uncaria tomentosa) [17] and greater total polyphenol content than garlic (Allium sativum L.) [18], which are two well characterized medicinal plants.

\section{CONCLUSION}

This is the first report that has quantified various wellcharacterized polyphenols in $P$. aduncum L. and the first study in assessing its anti-oxidant capacity, reducing power, and capacity to scavenge hydrogen peroxide, and reducing power, which may be a rational explanation for the therapeutic application of the herb in Latin American medicine.

\section{ACKNOWLEDGMENTS}

The authors would like to acknowledge the Consejo Nacional de Ciencia y Tecnología (CONCYTEC) for a research grant to MRE, a research grant from the Organic Center to NMD, and a research fellowship from the Organic Center to JAY and an equipment grant from Shimadzu to NMD. CMR is the recipient of a United States Pharmacopeia fellowship.

\section{REFERENCES}

[1] Formica, J.V.; Regelson, W. Food Chem. Toxicol., 1995, 33, 1061.

[2] So, F.V.; Guthrie, N.; Chambers, A.F.; Moussa, M.; Carroll, K.K. Nutr. Cancer, 1996, 26, 167.

[3] Morandim, A.A.; Bergamo, D.C.B.; Kato, M.J.; Cavalheiro, A.J.; da S. Bolzani, V.; Furlan, M. Phytochem. Anal., 2005, 16, 282.

[4] Mikich, S.B.; Bianconi, G.V.; Maia, B.H.; Teixeira, S.D. J. Chem. Ecol., 2003, 29, 2379.
[5] Parmar, V.S.; Jain, S.C.; Bisht, K.S.; Jain, R.; Taneja, P.; Jha, A.; Tyagi, O.D.; Prasad, A.K.; Wengel, J.; Olsen, C.E.; Boll, P.M. Phytochemistry, 1997, 46, 597.

[6] Mostacero, J.; Mejia, F.; Gamarra, O. In Consejo Nacional de Ciencia, Tecnología e Innovacion Tecnologica; CONCYTEC, Normas, L.S. Ed.; 2002; Vol. 1-2, pp. 232.

[7] Cronquist, A. An Integrated System of Classification of Flowering Plants; Columbia University Press: New York, 1981.

[8] Schieber, A.; Keller, P.; Carle, R. J. Chromatogr. A, 2001, 910, 265.

[9] Brand-Williams, W.; Cuvelier, M.; Berset, C. Lebensmittel Wissenschaft und Technologie, 1995, 28, 25.

[10] Ruch, R.; Cheng, S.; Klauning, J. Carcinogenesis, 1989, 10, 2123.

[11] Oyaizu, M. Jpn. J. Nutr., 1986, 44, 307.

[12] Price, M.L.; Butler, L.G. J. Agric. Food Chem., 1977, 25, 1268.

[13] Folgarait, P.J.; Davidson, D.W. Oikos, 1994, 71, 305.

[14] Machado, L.R.; Sharapin, N. In Segundo Congreso Internacional y Segundo Congreso Peruano de Plantas Medicinales y Fitoterapia, Lima, Peru, 2003; pp. 13-20.

[15] du Toit, R.; Volsteedt, Y.; Apostolides, Z. Toxicology, 2001, 166, 63.

[16] Cos, P.; Ying, L.; Calomme, M.; Hu, J.P.; Cimanga, K.; Van Poel, B.; Pieters, L.; Vlietinck, A.J.; Vanden Berghe, D. J. Nat. Prod., 1998, 61, 71 .

[17] Goncalves, C.; Dinis, T.; Batista, M.T. Phytochemistry, 2005, 66, 89.

[18] Tapsell, L.C.; Hemphill, I.; Cobiac, L.; Patch, C.S.; Sullivan, D.R.; Fenech, M.; Roodenrys, S.; Keogh, J.B.; Clifton, P.M.; Williams, P.G.; Fazio, V.A.; Inge, K.E. Med. J. Aust., 2006, 185, S4.

(c) Ramos Escudero et al.; Licensee Bentham Open.

This is an open access article licensed under the terms of the Creative Commons Attribution Non-Commercial License (http://creativecommons.org/licenses/by$\mathrm{nc} / 3.0 /$ /) which permits unrestricted, non-commercial use, distribution and reproduction in any medium, provided the work is properly cited. 